\title{
Study of Hydrometeorology in a Hard Rock Terrain, Kadirischist Belt Area, Anantapur District, Andhra Pradesh
}

\author{
Katta Satya Sai Prasad, Purrumreddy Tirumala Ashok Kumar Reddy, \\ Nagam Balayerikala Reddy \\ Department of Geology, Sri Venkateswara University, Tirupati, India \\ Email:ksspsvu@gmail.com
}

Received May 25, 2012; revised June 21, 2012; accepted July 20, 2012

\begin{abstract}
Hydrometeorological studies reveal that the study area comes under semi-arid zone with moderate drought conditions. The rainfall confirms that erratic nature of rainfall in the study area. The rainfall data for 14 years of the study area reveal that only three years had sufficient rainfall and rest of the 11 years are drought-prone to varying intensities. It is also observed that the area receives maximum amount of rainfall from south-west monsoon (June-December).
\end{abstract}

Keywords: Hydrometeorology; Rainfall Ratio; Drought and Hydrograph

\section{Introduction}

Geological factors, soils and vegetation influence the distribution of water. However, it is mainly weather and climate that form and sustain lakes and rivers create deserts and produce floods and droughts. This is because the source of all fresh water is the rain and snow, which falls from the clouds and the main loss of water, is what returns to the atmosphere through the process of evaporation. These are some of the facts of the hydrological cycle that accounts for the never-ending movement of water from the atmosphere to the ground by precipitation, then to rivers, lakes and underground reservoirs and to the sea. Most of the water vapor present in the atmosphere is derived from the salty seas by evaporation. The hydrological cycle is nature's great desalinization plant by which saline seawater is converted into water vapor and then into fresh waters that fall on the ground as rain, and snow.

All the water that replenishes our rivers, lakes and wells must pass through the atmosphere. Thus, the rivers and groundwater on which we depend are controlled by atmospheric events. It is obvious that the weather exerts the major influence on the varying geographical distribution of water.

STUDY AREA:

The investigated area forms a portion of Kadiri schist belt, lies between North Latitudes $14^{\circ} 1^{\prime}$ and $14^{\circ} 10^{\prime}$ and East Longitudes $78^{\circ} 05^{\prime}$ and $78^{\circ} 15^{\prime}$, is one of the chronically drought affected areas of Anantapur district, Andhra Pradesh (Figure 1). It is a linear greenstone belt situated in the eastern part of the Dharwar Craton and southwestern part of the Cuddapah Basin.

\section{Method}

The rainfall data are collected form the Indian meteorological department of Anantapur and analyzing spatial distribution of the rainfall to know the hydrometeorological conditions like type of drought in the study area by using the rainfall ratio mentioned by Bhargava [1].

\section{Results}

\section{Hydrometeorological Elements}

Hydrometeorology is the science that deals with the application of meteorology to water problem. Hydrometeorlogical conditions mainly deal with the climatologically conditions, which affect groundwater of an area.

Climate: The area is a part of the chronically droughtaffected district (Anantapur) of Andhra Pradesh and falling in the rain-shadow region of Peninsular India. The study area receives erratic and scanty rainfall. This area experiences hot summers and mild winters. During December-January the temperature is the lowest touching $20^{\circ} \mathrm{C}$ and during April-May the temperature shoots up to $42^{\circ} \mathrm{C}$. Humidity varies from 75 to 85 percent in rainy season and is almost dry $(20 \%$ to $25 \%)$ during the period May and June. Wind speeds are generally light to moderate, but become stronger during the southwest monsoon period. During this period the average wind velocity varies from $18 \mathrm{~km} / \mathrm{h}$ to $28 \mathrm{~km} / \mathrm{h}$, whereas it lowers to 8 to 


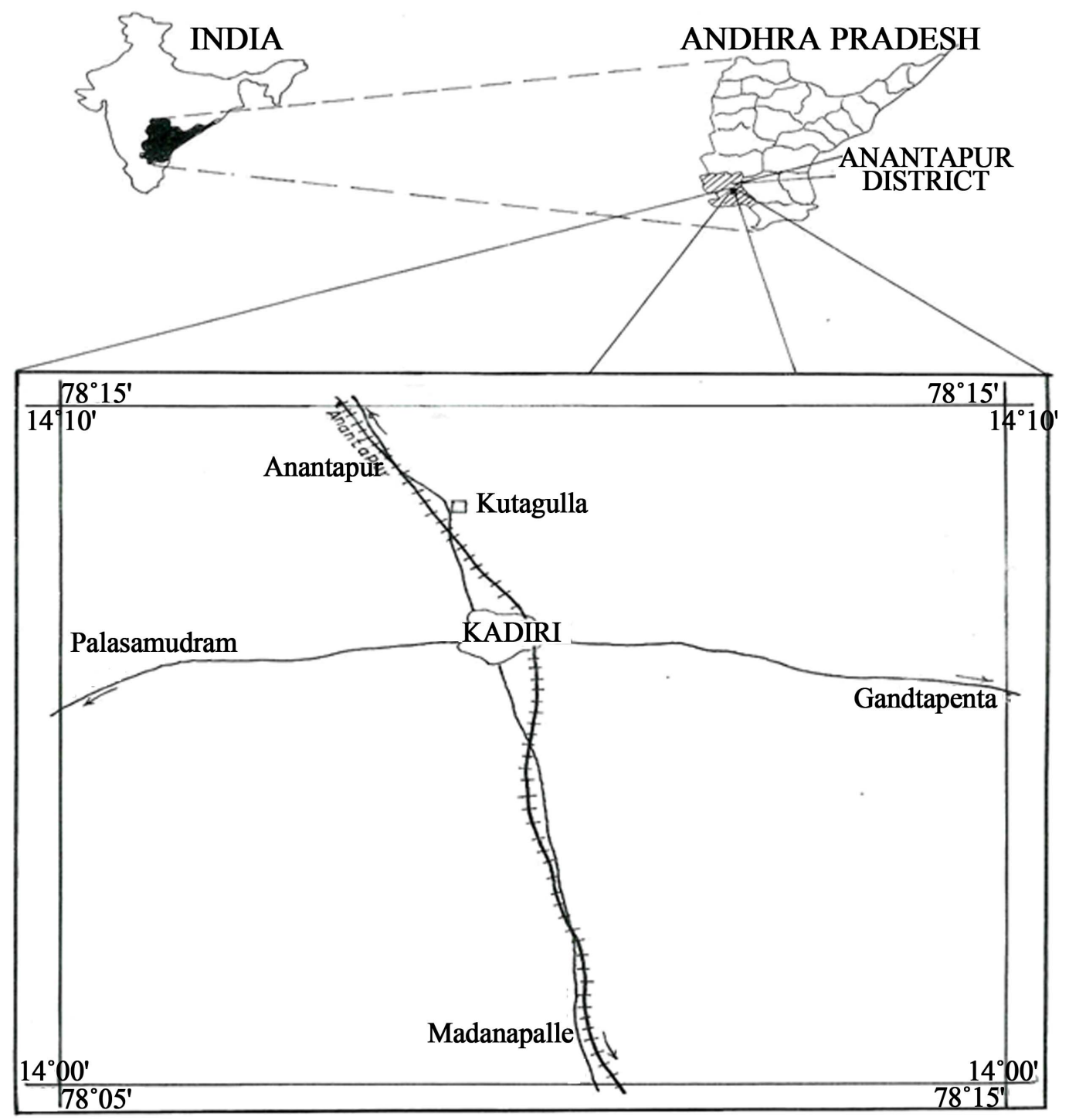

Figure 1. Location map of the area investigated.

$12 \mathrm{~km} / \mathrm{h}$ during October and November (northeast monsoon period).

Precipitation: Rainfall data are collected for four rainguage stations in and around the study area from the meteorological department of Anantapur. The minimum, maximum and mean rainfall data is presented for the four-rainguage stations in Table 1. The monthly and annual rainfall data of Kadiri rainguage station from 1990 to 2003 is given in the Table 2. The annual rainfall at Kadiri station ranges from $2037 \mathrm{~mm}$ (in 1998) to 394 $\mathrm{mm}$ (in 2002) with a mean value of $785 \mathrm{~mm}$. From the Figure 2 it is observed that the rainfall is deviated positively the years 1996, 1998 and 2002, but it shows negative deviation in the rest of the eleven years. The minimum rainfall in the month of January and maximum in the months of August to October are noticed (Table 2). The southwest monsoon during June to August contri- butes to $62 \%$ of the rainfall. The northeast monsoon, which breaks in the month of September, brings $27 \%$ of rainfall until December (Table 3 ). The heavy rainfall is due to the cyclone depressions and storms caused in the Bay of Bengal during the period of northeast monsoon.

Rainfall Ratio: According to Bhargava [1] the rainfall ratio is defined as the abnormalities in the occurrence of rainfall at any location. It can be obtained from the formula given below:

$$
\text { Rainfall Ratio }=\frac{\mathrm{P}_{\mathrm{x}}-\mathrm{P}_{\mathrm{mx}}}{\mathrm{P}_{\mathrm{n}}} \times 100
$$

where $P_{x}=$ Maximum yearly rainfall;

$\mathrm{P}_{\mathrm{m}}=$ Minimum yearly rainfall;

$\mathrm{P}_{\mathrm{n}}=$ Average yearly rainfall.

The high rainfall ratio indicates high abnormalities, whereas low ratio indicates greater stability of rainfall. 
Table 1. Annual rainfall data in and around the study area for 14 years (1990-2003).

\begin{tabular}{|c|c|c|c|c|c|}
\hline S. No & Year & Kadiri (in mm) & O. D. Cheruvu (in mm) & Gandlapenta (in mm) & Nallacheruvu (in mm) \\
\hline 1 & 1990 & 596.4 & 513.8 & 690.5 & 437.7 \\
\hline 2 & 1991 & 559.6 & 875.2 & 886.6 & 703.2 \\
\hline 3 & 1992 & 438.4 & 552.8 & 501.6 & 521.2 \\
\hline 4 & 1993 & 527.4 & 464.0 & 596.8 & 567.3 \\
\hline 5 & 1994 & 466.0 & 537.0 & 352.8 & 463.2 \\
\hline 6 & 1995 & 738.4 & 695.0 & 589.8 & 565.8 \\
\hline 7 & 1996 & 1243.0 & 1221.4 & 1050.6 & 770.0 \\
\hline 8 & 1997 & 664.6 & 618.0 & 576.0 & 555.6 \\
\hline 9 & 1998 & 2037.6 & 519.0 & 714.6 & 718.2 \\
\hline 10 & 1999 & 436.6 & 352.0 & 405.8 & 308.4 \\
\hline 11 & 2000 & 991.4 & 604.8 & 721.2 & 395.8 \\
\hline 12 & 2001 & 589.4 & 601.6 & 896.0 & 790.9 \\
\hline 13 & 2002 & 394.4 & 504.8 & 282.8 & 378.2 \\
\hline 14 & 2003 & 573.0 & 330.6 & 605.0 & 529.6 \\
\hline \multicolumn{2}{|c|}{ Maximum } & 2037.6 & 1221.4 & 1050.6 & 790.9 \\
\hline \multicolumn{2}{|c|}{ Minimum } & 394.4 & 338.6 & 282.8 & 308.4 \\
\hline \multicolumn{2}{|c|}{ Mean } & 785.3 & 599.3 & 605.0 & 550.4 \\
\hline
\end{tabular}

Table 2. Monthly rainfall data of kadiri rain-gauge station (in $\mathbf{m m}$ ).

\begin{tabular}{|c|c|c|c|c|c|c|c|c|c|c|c|c|c|}
\hline Year & Jan & Feb & Mar & Apr & May & Jun & Jul & Aug & Sep & Oct & Nov & Dec & Ann. Rain fall \\
\hline 1990 & 0.0 & 0.0 & 39.2 & 0.0 & 117.8 & 57.8 & 27.6 & 92.2 & 95.6 & 67.6 & 98.6 & 0.0 & 596.4 \\
\hline 1991 & 0.0 & 0.0 & 0.0 & 23.0 & 54.2 & 103.2 & 31.8 & 69.8 & 2.2 & 261.0 & 113.4 & 0.0 & 559.6 \\
\hline 1992 & 0.0 & 0.0 & 0.0 & 0.0 & 30.2 & 35.8 & 37.2 & 99.2 & 60.0 & 63.0 & 113.0 & 0.0 & 438.4 \\
\hline 1993 & 0.0 & 0.0 & 6.2 & 0.0 & 15.6 & 45.2 & 93.4 & 67.0 & 72.0 & 132.8 & 40.8 & 54.4 & 527.4 \\
\hline 1994 & 0.0 & 0.0 & 0.0 & 7.0 & 114.0 & 41.6 & 61.8 & 18.2 & 7.0 & 162.6 & 46.8 & 7.0 & 466.0 \\
\hline 1995 & 4.8 & 0.0 & 23.4 & 0.0 & 53.8 & 57.6 & 214.6 & 117.0 & 178.6 & 88.6 & 0.0 & 0.0 & 738.4 \\
\hline 1996 & 0.0 & 0.0 & 0.0 & 100.6 & 22.0 & 270.8 & 74.4 & 145.2 & 288.8 & 311.2 & 16.0 & 14.0 & 1243.0 \\
\hline 1997 & 0.0 & 0.0 & 64.6 & 37.2 & 0.0 & 108.0 & 2.4 & 130.8 & 163.6 & 66.4 & 64.2 & 27.4 & 664.6 \\
\hline 1998 & 0.0 & 0.0 & 0.0 & 9.0 & 47.2 & 66.2 & 160.6 & 1644.0 & 110.6 & 0.0 & 0.0 & 0.0 & 2037.6 \\
\hline 1999 & 0.0 & 0.0 & 0.0 & 0.0 & 0.0 & 57.2 & 64.6 & 66.0 & 101.4 & 89.4 & 52.0 & 6.0 & 436.6 \\
\hline 2000 & 0.0 & 50.0 & 0.0 & 0.0 & 159.2 & 82.4 & 105.0 & 292.2 & 133.2 & 151.6 & 5.6 & 12.4 & 991.4 \\
\hline 2001 & 0.0 & 0.0 & 4.6 & 99.4 & 18.8 & 44.2 & 29.6 & 91.2 & 164.8 & 355.2 & 45.6 & 5.0 & 589.4 \\
\hline 2002 & 0.0 & 0.0 & 0.0 & 48.4 & 46.2 & 24.8 & 19.6 & 25.0 & 94.0 & 116.0 & 17.2 & 3.2 & 394.4 \\
\hline 2003 & 0.0 & 0.0 & 0.0 & 8.2 & 0.0 & 62.8 & 103.0 & 74.6 & 58.0 & 251.2 & 2.2 & 0.0 & 573.0 \\
\hline
\end{tabular}




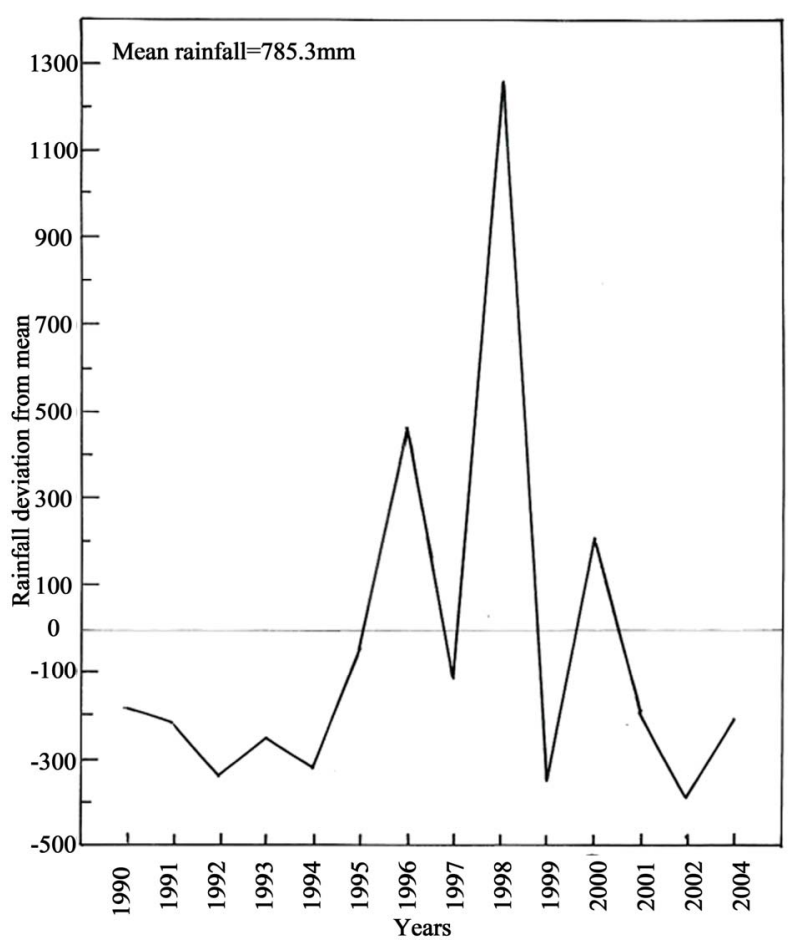

Figure 2. The deviation of the rainfall from the mean annual rainfall.

Table 3. Percentage precipitation in the study area (in $\mathbf{m m}$ ).

\begin{tabular}{ccc}
\hline S. No & Period & $\begin{array}{c}\text { Percentage of } \\
\text { precipitation }\end{array}$ \\
\hline 1 & $\begin{array}{c}\text { South-West Monsoon } \\
\text { (Jun, Jul, Aug and Sept.) } \\
\text { North-East Monsoon } \\
\text { (Oct, Nov and Dec.) }\end{array}$ & $61.6 \%$ \\
2 & $\begin{array}{c}\text { Torential (Hot) Weather } \\
\text { (Feb to May) }\end{array}$ & $10.9 \%$ \\
\hline
\end{tabular}

The rainfall ratio of the study area shows very high values (i.e., 180 to 962) denoting that there is much variation in annual rainfall from the normal rain of year (Table 5). It confirms the erratic nature of rainfall in the study area.

\section{Discussion}

\subsection{Identification of Drought Types}

The Indian Meteorological Department (IMD) has taken deviation from the mean annual rainfall for describing the drought intensity. It is considered that if the deviation from the mean lies between $10 \%$ and $20 \%$ - Slightly Drought 20\% and 30\%-Moderate Drought 30\% and $40 \%$ - Severe Drought and above $40 \%$ - Disastrous.

From the Table 4 it is observed that in the 14 years period only three years $(1966,1998$ and 2000) are positive and rest of the 11 years are drought-prone with varying intensities. Out of the 11, 4 years (1992, 1994,
Table 4. Rainfall deviation and rainfall ratio for the study area.

\begin{tabular}{cccc}
\hline Year & Deviation & \% of Deviation & Rainfall Ratio \\
\hline 1990 & -186.9 & 24 & 180 \\
1991 & -225.7 & 29 & 470 \\
1992 & -346.9 & 44 & 230 \\
1993 & -257.9 & 33 & 290 \\
1994 & -319.3 & 41 & 400 \\
1995 & -46.9 & 06 & 340 \\
1996 & +457.7 & - & 290 \\
1997 & -120.7 & 15 & 290 \\
1998 & +1252.3 & - & 962 \\
1999 & -348.7 & 44 & 262 \\
2000 & +206.1 & - & 346 \\
2001 & -195.9 & 25 & 496 \\
2002 & -390.9 & 50 & 343 \\
2003 & -212.3 & 27 & 522 \\
\hline
\end{tabular}

1999 and 2002) experienced disastrous type of drought with more than $40 \%$ of deviation from the mean annual rainfall. Only the year 1993 comes under severe type with $33 \%$ and the rest of the six years have experienced moderate to slightly drought conditions.

\subsection{Water Table Characteristics}

The movement of groundwater in the weathered and fractured rocks is dependent on the degree of inter-connecting interstices, topography, and conditions of recharge and discharge. The thickness of the zone of saturation is also dependent on the said factors. The zone of saturation generally follows the configuration of the topography of the area. In general, the water level starts to rise from the month of July, and continues up to December depending on the amount of precipitation, while it starts to decline from the month of January and continues up to the end of June.

An inventory of 41 wells in the study area enables us to understand the hydrodynamic characteristics of the study area. The depth to water table is recorded for all the wells. The altitude of the wells is determined by using GPS. While collecting the data, sufficient care is taken to avoid perched aquifers. The water table levels are recorded during the pre-monsoon (June, 2002) season and post-monsoon (January, 2003) seasons (Table 5). Water table maps of the area with respect to the mean sea level (MSL) are prepared for both pre- and post-monsoon seasons (Figures 3 and 4). 
Table 5. Water table fluctuations of the study area (in $\mathbf{m}$ ).

\begin{tabular}{|c|c|c|c|c|c|}
\hline S.No & Location & Well Depth (m) & $\begin{array}{l}\text { Water table in Pre-Monsoon } \\
\text { (above MSL) }\end{array}$ & $\begin{array}{l}\text { Water table in Post-monsoon } \\
\text { (above MSL) }\end{array}$ & $\begin{array}{c}\text { Difference in } \\
\text { Watertable (in } \mathrm{m} \text { ) }\end{array}$ \\
\hline 1 & Allipur Tanda-1 & 8 & 499.6 & 503.8 & 4.2 \\
\hline 2 & Gollavari Palle & 6 & 513.2 & 515.8 & 2.6 \\
\hline 3 & Mutyalacharuvu & 9 & 500.2 & 503.6 & 3.4 \\
\hline 4 & Battalapalle-1 & 6 & 496.2 & 500.8 & 4.6 \\
\hline 5 & Battalapalle-2 & 10 & 503.2 & 506.0 & 2.8 \\
\hline 6 & Eguvapalle & 8 & 577.0 & 580.6 & 3.6 \\
\hline 7 & Mallayyagaripalle & 11 & 546.9 & 551.0 & 4.1 \\
\hline 8 & Kareddipalle & 8 & 514.5 & 517.8 & 3.3 \\
\hline 9 & Tellaguntapalle & 11 & 555.0 & 558.8 & 3.8 \\
\hline 10 & Tavalamarri & 10 & 553.2 & 557.4 & 4.2 \\
\hline 11 & Mustipalle & 12 & 594.4 & 598.2 & 3.8 \\
\hline 12 & Tummalabayulu & 7 & 604.4 & 608.8 & 4.4 \\
\hline 13 & Gangannagaripalle & 8 & 506.6 & 509.8 & 3.2 \\
\hline 14 & Chittivaripalle & 6 & 556.2 & 560.8 & 4.6 \\
\hline 15 & Burugapalle & 9 & 572.4 & 577.6 & 5.2 \\
\hline 16 & Pulikuntapalle & 10 & 611.4 & 617.2 & 5.8 \\
\hline 17 & Tirumalavaripalle & 9 & 514.2 & 517.4 & 3.2 \\
\hline 18 & Sivarampalle & 11 & 521.8 & 524.9 & 3.1 \\
\hline 19 & Pantulacharuvu & 8 & 526.9 & 529.7 & 2.8 \\
\hline 20 & Boyaramayyapalle & 10 & 554.3 & 558.9 & 4.6 \\
\hline 21 & Erradoddi Tanda & 12 & 477.2 & 482.4 & 5.2 \\
\hline 22 & Kummaravaripalle & 11 & 487.8 & 492.6 & 4.8 \\
\hline 23 & Barigareddipalle & 8 & 509.1 & 513.2 & 4.1 \\
\hline 24 & Nillavaripalle & 9 & 554.8 & 557.8 & 3.0 \\
\hline 25 & Allipur Tanda-2 & 7 & 475.2 & 478.0 & 2.8 \\
\hline 26 & Devaracharuvu Lands & 6 & 457.5 & 460.4 & 2.9 \\
\hline 27 & Metukupalle & 9 & 550.7 & 553.2 & 2.5 \\
\hline 28 & Nagireddipalle & 11 & 521.0 & 524.7 & 3.7 \\
\hline 29 & Beripalle Lands & 12 & 488.7 & 492.6 & 3.9 \\
\hline 30 & Sidapuram & 8 & 502.7 & 505.9 & 3.2 \\
\hline 31 & Kuttagulla & 11 & 482.4 & 486.7 & 4.3 \\
\hline 32 & Errakuntapalle & 19 & 503.4 & 509.2 & 5.8 \\
\hline 33 & Kadiri & 10 & 474.1 & 478.9 & 4.8 \\
\hline 34 & Kavulapalle & 8 & 503.6 & 507.2 & 3.6 \\
\hline 35 & Jagannapeta & 16 & 521.6 & 527.8 & 6.2 \\
\hline 36 & Kottapalle & 14 & 531.7 & 536.1 & 4.4 \\
\hline 37 & Payalavandapalle & 18 & 571.4 & 575.2 & 3.8 \\
\hline 38 & Allugunda & 8 & 553.0 & 557.2 & 4.2 \\
\hline 39 & Nallacheruvu RS & 14 & 544.8 & 550.4 & 5.6 \\
\hline 40 & Rangannagari Palle & 12 & 564.3 & 568.9 & 4.6 \\
\hline 41 & Deverintipalle & 10 & 560.8 & 564.8 & 3.8 \\
\hline Min & & 6 & 474.1 & 478.0 & 2.6 \\
\hline Max & & 19 & 611.4 & 617.2 & 6.2 \\
\hline
\end{tabular}




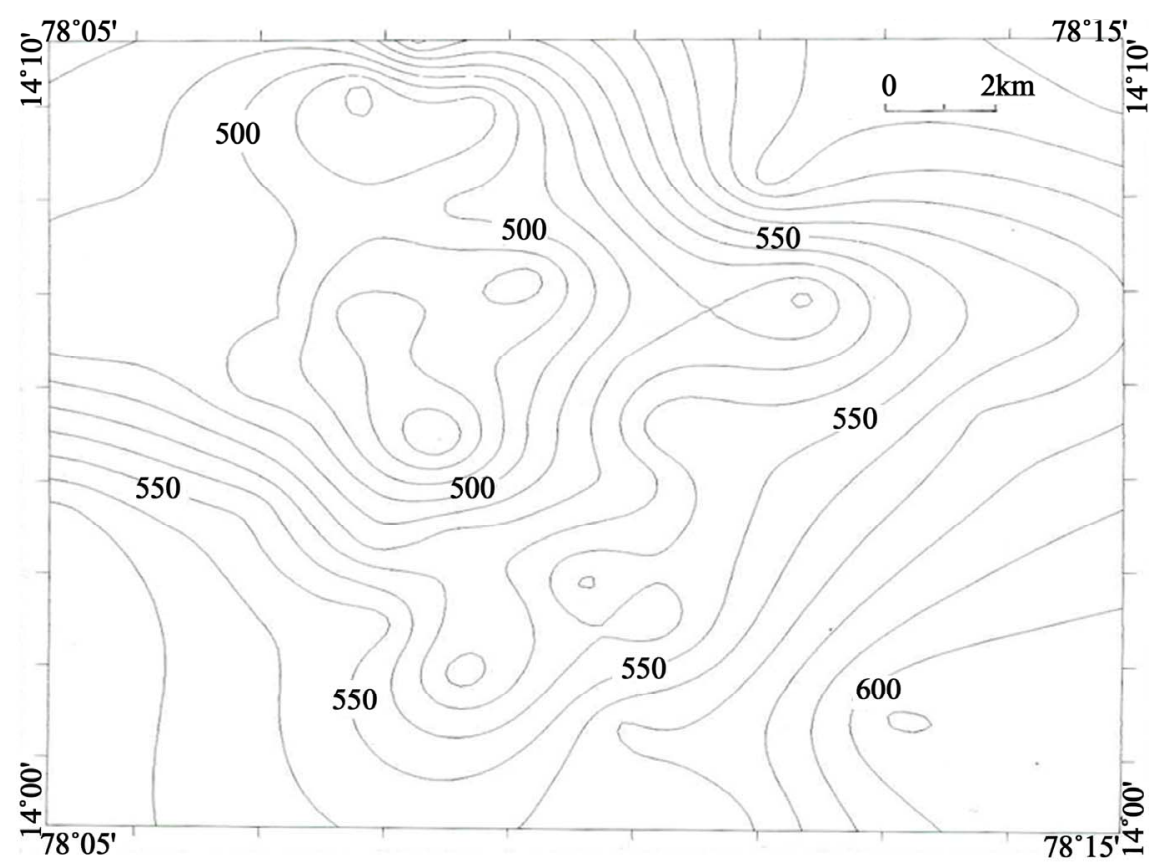

Figure 3. Water table fluctuation map (pre-monsoon) of the study area.

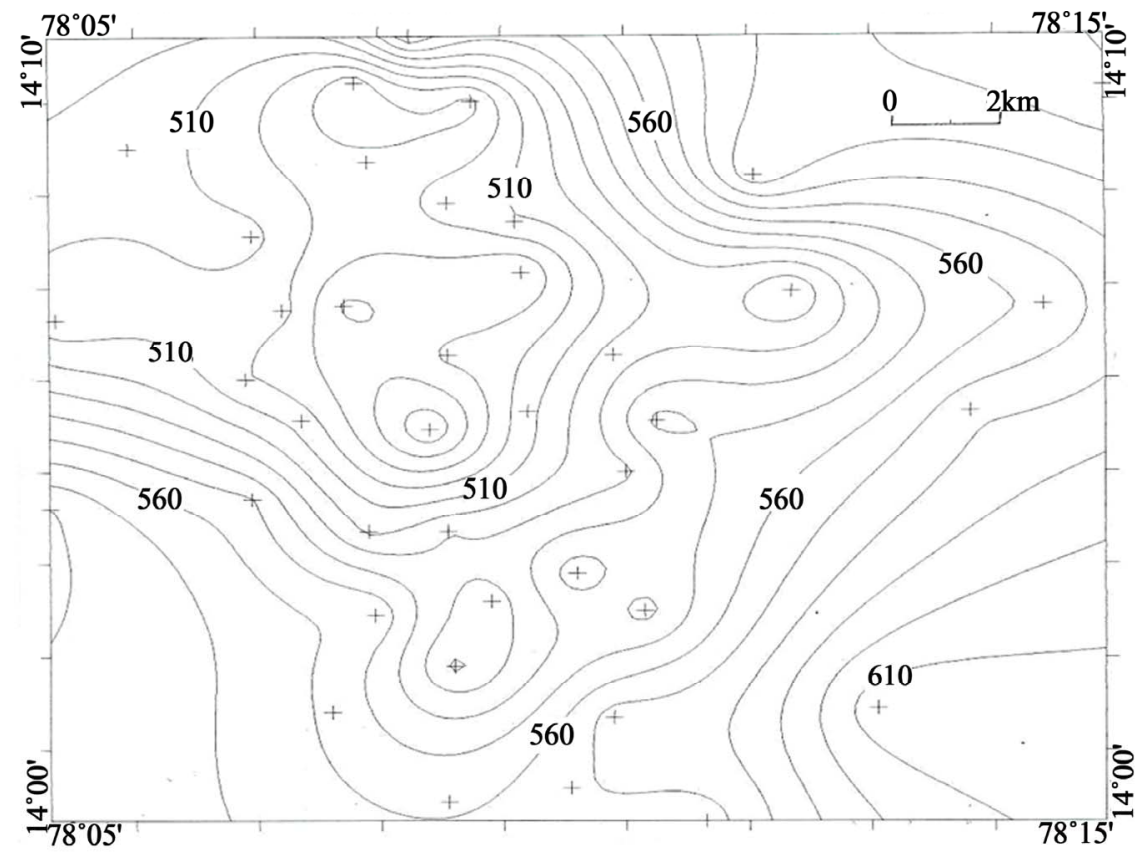

Figure 4. Water table fluctuation map (post-monsoon) of the study area.

Water level variations in the study area depend on the amount of precipitation, influent and effluent nature of the streams, geology of the area, slope of the area and infiltration capacity of the soils. The seasonal variations in the ground water also correlate with the data of the rainfall. The water level has shown a rise during November-December months due to the rainfall percolation during October to December months. This clearly reveals that there is a net recharge of groundwater due to the influence of rainfall only. The water level starts to decline from the month of February and reaches maximum in the month of June. This is mainly due to the depletion of rainfall and groundwater withdrawals for irrigation.

The fluctuations in the water table level have direct relationship with rainfall in the study area. The factors like intensity of rainfall and its variation with time and place, temperature, surface and sub-surface soil characteristics and vegetation cover play an important role in 


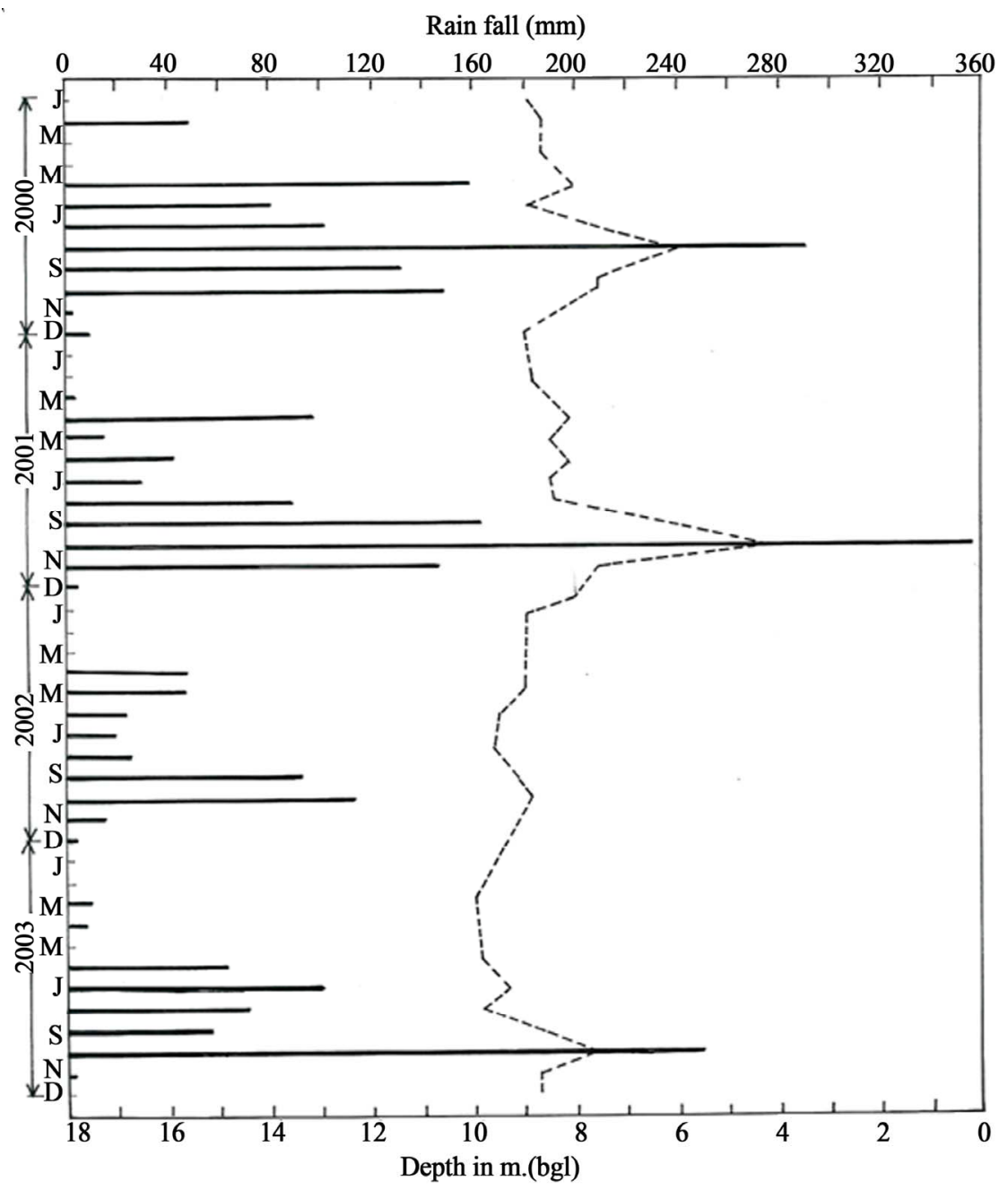

Figure 5. Hydrograph of the Kadiri area.

the water level fluctuations besides topography.

\subsection{Hydrograph}

The monthly water table levels in observation wells of Kadiri and its surroundings for a period of four years (2000 to 2003) correlate with the monthly values of rainfall data (Figure 5). From the observation of the hydrograph, it is noticed that the rise of water level starts immediately after the soil moisture reaches its maximum water-holding capacity. The water table level rises to a maximum in the months of November and December.

The groundwater levels show seasonal fluctuations influenced by rainfall and pumping of water from the wells for irrigation. In general, water level gradually increases during post-monsoon period (i.e., from June to December) and decreases during pre-monsoon period (i.e., January to June). Changes in climate also produce water level fluctuations in the wells. During post-monsoon period, the climate is cool and evaporation less while during premonsoon season, the climate is hot and evaporation more.

\section{Conclusion}

Hydrometeorological studies reveal that the study area comes under semi-arid zone. The rainfall data for 14 years (1900 to 2003) of the study area reveal that only three years (1996, 1998 and 2003) had sufficient rainfall and rest of the 11 years are drought-prone to varying intensities. It is also observed that the water table gradually increases during the June to December (post-monsoon) and decreases during January to June (pre-monsoon). The fluctuations in water table vary from $2.6 \mathrm{~m}$ to $6.2 \mathrm{~m}$ with a mean value of $4.01 \mathrm{~m}$. The area receives maximum amount of rainfall from south-west monsoon.

\section{REFERENCES}

[1] P. N. Bhargava, "Statistical Studies on the Behaviour of Rainfall in a Region in Relation to a Crop," Indian Agricultural Research Station and Indian Council of Agricultural Research, New Delhi, 1977. 